\title{
Growing pains: contemporary knowledge and recommended practice
}

\author{
Angela M Evans
}

Address: School of Health Science, Division of Health Science, University of South Australia, City East Campus, North Terrace, Adelaide, 5000, Australia

Email: Angela M Evans - angela.evans@unisa.edu.au

Published: 28 July 2008

Journal of Foot and Ankle Research 2008, I:4 doi:10.1 I86/I757-II46-I-4

This article is available from: http://www.jfootankleres.com/content/I/I/4

(c) 2008 Evans; licensee BioMed Central Ltd.

This is an Open Access article distributed under the terms of the Creative Commons Attribution License (http://creativecommons.org/licenses/by/2.0), which permits unrestricted use, distribution, and reproduction in any medium, provided the original work is properly cited.

\begin{abstract}
Background: Leg pain in children, described as growing pains, is a frequent clinical presentation seen by an array of health care professionals. Described since 1823, growing pains continues to puzzle practitioners, yet diagnostic criteria and evidence based treatment is available.

Methods: The medical literature has been searched exhaustively to access all articles (English language) pertaining to leg pains in children which are ascribed to being 'growing pains'.

Results: The literature, whilst plentiful in quantity and spanning two centuries, is generally replete with reiterated opinion and anecdote and lacking in scientific rigour. The author searched 45 articles for relevance, determined according to title, abstract and full text, resulting in a yield of 22 original studies and 23 review articles. From the original studies, one small (non-blinded) randomised controlled trial that focused on GP treatment with leg muscle stretching was found. Nine prevalence studies were found revealing disparate estimates. Ten cohort (some casecontrolled) studies, which investigated pain attribute differences in affected versus unaffected groups, were found. One series of single case experiment designs and one animal model study were found.

Conclusion: Growing pains is prevalent in young children, presents frequently in the health care setting where it is poorly managed and is continuing to be researched. A common childhood complaint, growing pains needs to be acknowledged and better managed in the contemporary medical setting.
\end{abstract}

\section{Background}

Growing pains first appeared as a described entity in the medical literature in 1823 following the observations of a French physician Marcel Duchamp [1]. Although the topic of many reports since that time [2-11], and despite being a frequent paediatric clinical presentation, growing pains remains largely misunderstood [12-14] and as a result poorly managed $[2,15]$. The purpose of this article is to compile a contemporary summary of what is known about growing pains and to provide a management guideline from the currently available scientific evidence.

\section{Methods}

The medical literature has been searched exhaustively to access all articles (English language) pertaining to leg pains in children which are ascribed to being 'growing pains'. It is important to note however, that growing pains (defined in Table 1) are not the same as all non-specific 
Table I: Definition of 'growing pains' - inclusion and exclusion criteria.

\begin{tabular}{|c|c|c|}
\hline Pain factors & Inclusion criteria & Exclusion criteria \\
\hline Nature of pain & $\begin{array}{l}\text { Intermittent } \\
\text { Some pain free days and nights }\end{array}$ & $\begin{array}{l}\text { Persistent } \\
\text { Increasing intensity }\end{array}$ \\
\hline Unilateral or bilateral & Bilateral & Unilateral \\
\hline Location of pain & Anterior thigh, calf, posterior knee - in muscles & Joint pain \\
\hline Onset of pain & Late afternoon or evening & Pain still present next morning \\
\hline Physical examination & Normal & $\begin{array}{l}\text { Swelling, erythema, tenderness } \\
\text { Local trauma or infection } \\
\text { Reduced joint range of motion } \\
\text { Limping }\end{array}$ \\
\hline Laboratory tests & Normal & Objective findings eg ESR, $x$-ray, bone scan abnormalities \\
\hline Limitation of activity & Nil & Reduced physical activity \\
\hline
\end{tabular}

leg pains. Many previous reviews have utilised the literature conveniently rather than comprehensively which has resulted in many incomplete and misleading articles amid the body of knowledge [16].

The subject search used a combination of controlled vocabulary, MeSH headings and free text terms based on the following search strategy for searching MEDLINE:

\# 1 growing pain* or leg pain* or leg ache*

\# 2 paediatric or pediatric or child*

\# 3 \#1 and \#2

The electronic databases searched were:

1. Cochrane Pain, Palliative \& Supportive Care Register (current issue)

2. The Cochrane Controlled Trials Register: Cochrane Library (current issue)

3. MEDLINE (1966 - present)

4. EMBASE (1980 - present)

5. CINAHL (1960 - present)

6. AMI (- present)

7. AMED (1985 - present)

8. Current Contents (1993 - present)

In addition, the reference lists of all eligible trials, key textbooks, and previous reviews were searched for additional studies.
The literature presents with recurring themes which have formed the basis for the structure of this present review. In this review, growing pains will be discussed under the following five sub-headings which reflect the body of knowledge found within the scientific literature: definition, prevalence, aetiology, associations and treatment.

\section{Results \\ Definition}

There is no single diagnostic test for growing pains and as a result it continues to be diagnosed on the basis of both inclusion and exclusion criteria $[2,15,17,18]$ (Table 1). Misdiagnoses of children with less common but potentially more serious conditions including rheumatoid arthritis (articular pain) or bone tumours (unlikely to be bilateral and night time occurrence) are unlikely if these criteria are adhered to and can be investigated further with blood analyses and imaging if suspected. A recent matched case-control study concluded that growing pain remains a clinical diagnosis and if precise inclusion and exclusion criteria are considered, there is no need for laboratory tests to make a diagnosis [19].

\section{Prevalence}

Studies of the prevalence of growing pains have presented a wide range of estimates from 2.6 to $49.4 \%$ [8,11,14,2023]. Poor sampling, disparate age ranges and nondefined, variable criteria account for much of this latitude. A robust prevalence study established the prevalence of growing pains in children aged four to six years as $37 \%$ [24].

\section{Aetiology}

Growing pains remains enigmatic in terms of its cause. Three main theories have been traditionally proposed as follows:

\section{Anatomical}

The anatomical theory emerged in the 1950's when the previously suspected association between growing pains 
and rheumatic fever had been overthrown [25]. Scoliosis, lordosis, genu valgum and flat feet have all been cited but unsubstantiated associations [20]. The anatomical theory centred on the premise that a cause of the pain was a postural or an orthopaedic defect that could induce bad posture or stance and that treatment of these 'defects' were clinically observed to give relief. The anatomical theory has recently been weakened with the research findings that foot posture and growing pains are uncorrelated [26].

\section{Fatigue}

The notion of muscular fatigue as the cause of growing pains was initiated by Bennie in 1894 from clinical case observations [4]. This theory has been periodically reiterated, focussing on a surmised accumulation of metabolic waste products within the leg muscles, but remains untested $[21,27,28]$. Parents will often associate episodes of growing pains with periods of increased physical activity [15].

\section{Psychological}

The emotional or psychological theory was introduced in 1951 [21] and has been further cited and addressed as possible causative factor by many authors since $[2,22,28,29]$. Increased vulnerability to pain has been suspected as has a familial predisposition. There is dissent regarding gender bias, where girls have historically been regarded as more susceptible [22]. Oberklaid investigated children with growing pains as part of a wider temperament survey and found that parents of affected children rated them to have a negative or intense mood [23].

\section{Further theories of pathogenesis}

Many investigations into the cause of growing pains have ensued in the last decade. Indeed, it is notable that this condition has continued to captivate clinicians and researchers with 185 years of reported history within the medical literature. Table 2 summarises the four recent studies which have developed new theory for the aetiology of growing pains, as referred to in the following text:

(i) Lower pain threshold: The pain threshold in children with growing pains has been found to be significantly reduced in comparison to an age and gender matched control group [30]. The authors suggest this may indicate that growing pains is a generalised non-inflammatory pain syndrome occurring in childhood.

(ii) Decreased bone strength: The speed of sound through bone was assessed using ultrasound and it was found that the bone strength density of the tibia in children with growing pains was significantly less than for normative data [31]. The authors postulate that bone fatigue with activity may give rise to the leg pains.

(iii) Altered vascular perfusion: Investigation of the uptake of technetium-99 during bone scans has been found not to differ in small samples of children with growing pains versus unmatched controls [32]. The authors hence refuted the hypothesis that growing pains may be induced by altered vascular perfusion in a manner similar to migraine headaches.

(iv) Joint hypermobility: There is untested clinical impression that children with growing pains may be hypermobile similarly to children with fibromyalgia $[33,34]$. As there is no universally reliable and valid assessment tool for hypermobility in children, support for this notion remains pending [35].

\section{Associations}

(i) The profile of affected children and the frequency of pain episodes has been recently reported [15]. Children with growing pains were found to be approximately 5\% heavier, but not taller than children not reporting growing pains. A positive family history of growing pains was reported, with affected children having either a parent or sibling having experienced growing pains in almost $70 \%$ of cases. Most children were reported to experience growing pains in spates with frequency of one to three months [15].

(ii) Previous studies have associated growing pains with abdominal pain, headache, as part of a pain triad $[29,36]$ an area which is still somewhat unclear.

Table 2: Summary of the recent studies which have established new aetiological theory for growing pains (GP).

\begin{tabular}{|c|c|c|c|c|c|}
\hline Date & First Author & $\begin{array}{l}\text { Sample } \\
\text { size }\end{array}$ & Research design & Findings & New theory \\
\hline 2004 & Hashkes, PJ & $\begin{array}{l}\text { GP group: } n=44 \\
\text { No GP control: } n=46\end{array}$ & $\begin{array}{l}\text { Case control } \\
\text { Dolorimeter (pressure) }\end{array}$ & $\begin{array}{l}\text { GP group had lower pain } \\
\text { thresholds }\end{array}$ & $\begin{array}{l}\text { GP may be a variant of a non- } \\
\text { inflammatory pain syndrome }\end{array}$ \\
\hline 2005 & Friedland, $\mathrm{O}$ & $\begin{array}{l}\text { GP group: } n=39 \\
\text { No GP control: } n=\end{array}$ & $\begin{array}{l}\text { Case control } \\
\text { Ultrasound bone speed, } \\
\text { tibia and radius }\end{array}$ & $\begin{array}{l}\text { GP group had reduced tibial } \\
\text { bone speed. }\end{array}$ & $\begin{array}{l}\text { GP may represent a local } \\
\text { overuse syndrome. }\end{array}$ \\
\hline 2005 & Hashkes, PJ & $\begin{array}{l}\text { GP group: } n=11 \\
\text { No GP control: } n=12\end{array}$ & $\begin{array}{l}\text { Case control } \\
\text { Bone scintigraphy, tibia }\end{array}$ & $\begin{array}{l}\text { GP group did not have altered } \\
\text { vascular perfusion when } \\
\text { compared with control group }\end{array}$ & $\begin{array}{l}\text { GP are not associated with } \\
\text { altered vascular perfusion as } \\
\text { opposed to migraine }\end{array}$ \\
\hline
\end{tabular}


(iii) Growth has been associated $[1,5,27,37-39]$ and disassociated $[2,12,13]$ with growing pains, but little investigation has ensued. Childhood is, by definition, a time of growth, but growth per se as a source of pain is uncertain and contentious $[40,41]$. Preliminary results found recumbent posture to be associated with increased tibial growth in three lambs [37]. Clearly this preliminary finding cannot be validly transposed to human subjects. Parents of children with growing pains associated growing pains and increased growth in 35\% of cases [15].

(iv) Increased levels of lead, zinc and decreased levels of copper and magnesium have been detected in the hair of children with growing pains, but the usefulness of the analysis of elements in hair remains controversial and has yet to be validated [42].

(v) Flatfeet have been postulated as an aetiological factor for growing pains for many years [20] with preliminary support from single case experiments [43]. A recent comparative study has however, found no clinically significant difference in the foot posture of children with or without growing pains [26].

(vi) Increased activity levels have been found to be associated by the parents of children with growing pains in $37 \%$ of reports [15]. Opinions over many years lend support to this preliminary finding $[4,23,34,39,44]$.

(vii) Children's quality of life (QoL) when affected with growing pains has been little investigated, despite being such a frequent clinical presentation $[2,45]$. It has been reported as a preliminary finding that parents assessed reduction in their child's QoL due to growing pains in some $5 \%$ of cases [15].

\section{Treatment}

There is only one randomised controlled trial which offers evidence for the treatment of children with growing pains, summarised in Table 3[46]. This small, non-blinded trial offers best (if limited) evidence for the management of growing pains with muscle stretching. Despite this being the best available evidence, it is not dispensed by health professionals who when infrequently consulted (only $34 \%$ of children were seen by health professionals [15]) dispense paracetamol. In addition, parents practice the time-honoured methods of rubbing children's legs and using hot water bottles during periods of distress [15].

Much lower on the evidence hierarchy, single case experiments supported the use of in-shoe wedges and foot orthoses [43]. In addition to the frequently practiced parental methods of treatment using paracetamol, leg rubs and heat, the literature is replete with many unfounded treatments including: vitamin $\mathrm{C}, \mathrm{D}$, magnesium, calcium, reassurance [34]. Clearly the first line treatment for growing pains should be that supported by (best available randomised controlled trial) evidence in the form of a muscle stretching program for the quadricep, hamstring and tricep surae groups [46]. Only once muscle stretching has been instituted should any supplementary treatments be appended, if needed.

\section{Conclusion}

Much has been written about growing pains over many years. In common with numerous medical conditions, there is much opinion and a relative paucity of sound science to guide clinicians. That being said, the last decade has seen some clarity and with confidence the contemporary clinician and researcher can be assuaged of the following tenets:

(i) Growing pains is prevalent in children aged four to six years $(37 \%)$

(ii) The diagnosis of growing pains is made clinically utilising both inclusion and exclusion criteria

(iii) Growing pains is familial

(iv) Growing pains is not associated with flat feet

Table 3: Summary of the only randomised controlled trial for treatment of growing pains (GP) (Baxter \& Dulberg, 1988).

\begin{tabular}{|c|c|c|}
\hline No. pain episodes per month & $\begin{array}{l}\text { Group I - treatment } \\
\text { Muscle stretching program * } \\
n=18\end{array}$ & $\begin{array}{l}\text { Group } 2 \text { - control } \\
\text { Reassurance, leg rubs, acetyl-salicylic acid } \\
n=16\end{array}$ \\
\hline Beginning of trial & 10 & 10 \\
\hline 3 months & 1 & 6 \\
\hline 9 months & 0 & 3 \\
\hline 18 months & 0 & 2 \\
\hline
\end{tabular}

The RCT for management of GP revealed a statistically significant difference between the treatment and control groups of children (aged $5-14$ years). However the study was biased, with no examiner blinding. Additionally, sample sizes are small and statistical power was not calculated. * Parents were taught a muscle stretching program for quadriceps, hamstrings and gastroc-soleal groups. All stretches were performed twice daily (morning and evening) for 10 minutes each time. 
(v) Health professionals are usually not consulted and the most practiced methods of management are paracetamol, rubbing legs and heat packs

(vi) The best evidence for management is muscle stretching of quadriceps, hamstrings and triceps surae groups

Contemporary practice should be informed an influenced by this current summary and by future research into this prevalent and frequently presenting childhood complaint.

\section{Competing interests}

The author declares that she has no competing interests.

\section{References}

I. Duchamp M: Maladies de la croissance. Memoires de Médecine Practique Paris, Jean-Frederic Lobstein 1823.

2. Al-Khattat A, Campbell J: Recurrent limb pain in childhood ('growing pains'). Foot 2000, 10:1 17-123.

3. Apley J: Clinical canutes: A philosophy of pediatrics. Proc Royal Soc Med 1970, 63(5):479-484.

4. Bennie P: Growing pains. Arch Pediatr 1894, I I(5): 10.

5. Brady M, Grey M: Growing pains: a myth or reality. J Pediatr Health Care 1989, 3(4):219-220.

6. Cullen $\mathrm{K}$, Macdonald $\mathrm{W}$ : The periodic syndrome: its nature and prevalence. Med J Aust 1963, 2(5):167-73.

7. Hawksley J: Race, Rheumatism and Growing Pains. Arch Dis Child 1931, 6:303-306.

8. Oster J, Nielson A: Growing pain: a clinical investigation of a school population. Acta Paediatr Scand 1972, 61:329-334.

9. Sherry D: Limb pain in childhood. Pediatr Rev 1990, I 2(2):39-46.

10. Weiner SR: Growing pains. Am Fam Physician 1983, 27:|89-191.

1I. Williams M: Rheumatic conditions in school children. Lancet 1928, 6:720-721.

12. Craft A: Do growing pains exist? West J Med 1999, I 70(6):362-363.

13. Manners P: Are growing pains a myth? Aust Fam Physician 1999 , 28:124-127.

14. Mikkelsson M, Salminen J, Kautiainen H: Non-specific musculoskeletal pain in preadolescents. Prevalence and I-year persistance. Pain 1997, 73:29-35.

15. Evans A, Scutter S, Lang L, Dansie B: 'Growing pains' in young children: A study of the profile, experiences and quality of life issues of four to six year old children with recurrent leg pain. Foot 2006, 16(3): 120-124.

16. Goodyear-Smith F, Arroll B: Growing pains. Brit Med J 2006, 333(7566):456-457.

17. Peterson H: Leg aches. Pediatr Clin North Am 1977, 24(4):73 I-736.

18. Peterson H: Growing pains. Pediatr Clin North Am 1986, 33:1365-72.

19. Asadi-Pooya AA, Bordbar MR: Are laboratory tests necessary in making the diagnosis of limb pains typical for growing pains in children? Pediatr Int 2007, 49(6):833-5.

20. Brenning R: Growing pain. Acta Soc Med Ups 1960, 65:185-20I.

21. Naish JM, Apley J: "Growing pains": a clinical study of nonarthritis limb pains in children. Arch Dis Child 1951, 26: I34-40.

22. Abu-Arafeh I, Russell G: Recurrent limb pain in school children. Arch Dis Child 1996, 74:336-9.

23. Oberklaid F, Amos D, Liu C, Jarman F, Sanson A, Prior M: "Growing Pains": clinical and behavioral correlates in a community sample. J Dev Behav Pediatr 1997, 18(2): 102-6.

24. Evans AM, Scutter SD: Prevalence of "growing pains" in young children. J Pediatr 2004, I45(2):255-8.

25. Hawksley J: The nature of growing pains and their relation to rheumatism in children and adolescents. Brit Med J 1939:155-7.

26. Evans A, Scutter S: Are Foot Posture and Functional Health different in Children with Growing Pains? Pediatr Int 2007, 49:99I-6.
27. Hawksley ]: The nature of growing pains and their relation to rheumatism in children and adolescents. Brit Med J 1939:3.

28. Henrickson M, Passo M: Recognising patterns in chronic limb pain. Contemp Pediatr 1994, I I (3):33-40.

29. Oster J: Recurrent abdominal pain, headache and limb pain in children and adolescents. Pediatrics I972, 50(3):429-36.

30. Hashkes P, Friedland O, Jaber L, Cohen A, Wolach B, Uziel Y: Children with growing pains have decreased pain threshold. J Rheumatol 2004, 3 I:6 10-3.

3I. Friedland O, Hashkes PJ, Jaber L, Cohen A, Eliakim A, Wolach B, et al:: Decreased bone strength in children with growing pains as measured by quantitative ultrasound. I Rheumatol 2005 , 32:1354-7.

32. Hashkes PJ, Gorenberg M, Oren V, Friedland O, Uziel Y: Growing pains" in children are not associated with changes in vascular perfusion patterns in painful regions. Clin Rheumatol 2005, 24:342-5.

33. Gedalia A, Press J, Klein M, Buskila D: Joint hypermobility and fibromyalgia in school children. Ann Rheum Dis 1993, 52:494-6.

34. Uziel Y, Hashkes P: Growing pains in children. Pediatr Rheumatol Online J 2007, 5(I):5.

35. Geissen LJ van der, Liekens D, Rutgers KJ, Hartman A, Mulder PG, Oranje AP: Validation of beighton score and prevalence of connective tissue signs in $\mathbf{7 7 3}$ Dutch children. I Rheumatol 200I, 28(I 2):2726-30.

36. Aromaa $M$, Sillanpaa $M$, Rautava $P$, Helenius $H$ : Pain experience of children with headache and their families: a controlled study. Pediatrics 2000, 106:270-5.

37. Noonan K, Farnum C, Leiferman E, Lampl M, Markel M, Wilsman N Growing Pains: Are They Due to Increased Growth During Recumbency as Documented in a Lamb Model? J Pediatr Orthop 2004, 24(6):726-31.

38. Brown L: Growing pains. A possible mechanical explanation. Boston Med Surg J 1910, 162(13):3.

39. Kramer K: Analysing childhood growing pains. Aust Doctor 1993, 3:54-5.

40. Calabro J], Wachtel AE, Holgerson WB, Repice MM: Growing pains: fact or fiction? Postgrad Med 1976, 59:66-72.

41. De Inocencio J: Epidemiology of musculoskeletal pain in primary care. Arch Dis Child 2004, 89:43I-4.

42. Lech T: Lead, copper, zinc, and magnesium levels in hair of children and young people with some disorders of the osteomuscular articular system. Biological Trace Element Research 2002, 89:1II-25.

43. Evans AM: Relationship between "growing pains" and foot posture in children: Single-case experimental designs in clinical practice. J Am Podiatr Med Assoc 2003, 93(2): I I I-7.

44. Champion G: Growing pains: Limb pain syndrome in children with no organic disease. Pain manage 1985, December:69-7I.

45. Macarthur C, Wright JG, Srivastava R, Rosser W, Feldman W: Variability in physicians' reported ordering and perceived reassurance value of diagnostic tests in children with growing pains. Arch Pediatr Adolesc Med 1996, I 50:1072-6.

46. Baxter M, Dulberg C: "Growing Pains" in Childhood - A Proposal for Treatment. J Pediatr Orthop 1988, 8(402):6.

Publish with Bio Med Central and every scientist can read your work free of charge

"BioMed Central will be the most significant development for disseminating the results of biomedical research in our lifetime. "

Sir Paul Nurse, Cancer Research UK

Your research papers will be:

- available free of charge to the entire biomedical community

- peer reviewed and published immediately upon acceptance

- cited in PubMed and archived on PubMed Central

- yours - you keep the copyright 